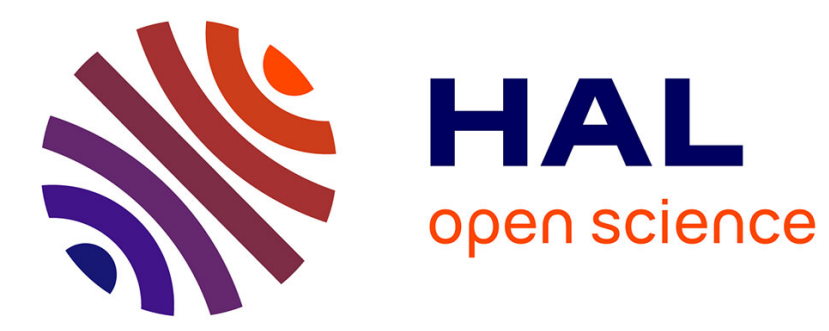

\title{
Synthesis, crystal structure and spectroscopic characterization of a new cadmium phosphate, $\mathrm{Na} 2 \mathrm{Cd} 5(\mathrm{PO} 4) 4$
}

Teycir Ben Hamed, Amal Boukhris, Benoit Glorieux, Mongi Ben Amara

\section{- To cite this version:}

Teycir Ben Hamed, Amal Boukhris, Benoit Glorieux, Mongi Ben Amara. Synthesis, crystal structure and spectroscopic characterization of a new cadmium phosphate, Na2Cd5(PO4)4. Journal of Molecular Structure, 2020, 1199, 126963 (10 p.). 10.1016/j.molstruc.2019.126963 . hal-02286674

\section{HAL Id: hal-02286674 \\ https://hal.science/hal-02286674}

Submitted on 9 Jun 2020

HAL is a multi-disciplinary open access archive for the deposit and dissemination of scientific research documents, whether they are published or not. The documents may come from teaching and research institutions in France or abroad, or from public or private research centers.
L'archive ouverte pluridisciplinaire HAL, est destinée au dépôt et à la diffusion de documents scientifiques de niveau recherche, publiés ou non, émanant des établissements d'enseignement et de recherche français ou étrangers, des laboratoires publics ou privés. 


\title{
Synthesis, crystal structure and spectroscopic characterization of a new cadmium phosphate, $\mathrm{Na}_{2} \mathrm{Cd}_{5}\left(\mathrm{PO}_{4}\right)_{4}$
}

\author{
Teycir Ben Hamed a , Amal Boukhris ${ }^{\text {a }}$, Benoit Glorieux ${ }^{\text {b }}$, Mongi Ben Amara a, * \\ a UR Matériaux Inorganiques, Faculté des Sciences, Université de Monastir, Avenue de l'Environnement, 5019, Monastir, Tunisia \\ ${ }^{\mathrm{b}}$ Institut de Chimie de la Matière Condensée de Bordeaux, CNRS, Université de Bordeaux I, 87 Avenue du Dr. A. Schweitzer, 33608, Pessac-Cedex, France
}

\section{A R T I C L E I N F O}

\section{Article history:}

Received 30 November 2018

Received in revised form

17 July 2019

Accepted 20 August 2019

Available online 23 August 2019

Keywords:

Phosphate

Crystal structure

Vibrational spectroscopy

Cadmium photoluminescence

\begin{abstract}
A B S T R A C T
A novel cadmium phosphate compound $\mathrm{Na}_{2} \mathrm{Cd}_{5}\left(\mathrm{PO}_{4}\right)_{4}$ was synthesized in single crystal and in powder forms using flux and Pechini methods, respectively. It was then characterized by single crystal X ray diffraction, vibrational spectroscopy and photoluminescence measurements. This compound crystallizes in the monoclinic system with space group $\mathrm{P} 21 / \mathrm{a}$, lattice parameters $a=8.276(1) \AA, b=9.301(3) \AA$, $c=9.455(2) \AA, \beta=111.82(1)^{\circ}$ and $Z=2$. The structure consists of $\left(\mathrm{Na}_{3 / 4}, \mathrm{Cd}_{1 / 4}\right) \mathrm{O}_{7},\left(\mathrm{Cd}_{3 / 4}, \mathrm{Na}_{1 / 4}\right) \mathrm{O}_{6}$ and $\mathrm{CdO}_{\mathrm{x}}(x=6,7)$, polyhedra and $\mathrm{PO}_{4}$ tetrahedra linked through common corners or edges giving rise to a novel type of complex three dimensional framework. This structure could be described in terms of $\left[\left(\mathrm{Na}_{3} /\right.\right.$ $\left.\left.{ }_{4}, \mathrm{Cd}_{1 / 4}\right)_{2}\left(\mathrm{Cd}_{3 / 4}, \mathrm{Na}_{1 / 4}\right)_{2} \mathrm{Cd}_{3} \mathrm{O}_{16}\right]_{\infty}$ layers stacked parallel to the $\left(\begin{array}{lll}2 & 0 & 3\end{array}\right)$ plane and interconnected both directly and via $\mathrm{PO}_{4}$ tetrahedra by sharing common corners and edges. Vibrational spectroscopy and cadmium photoluminescence were analyzed according to the structural results.
\end{abstract}

\section{Introduction}

Complex phosphates containing divalent cations are of increasing interest due to their large crystallographic characteris tics and their potential applications as host materials for optically active ions. By adjusting the composition and the structure of a compound, its optical features can be easily modulated as it has been observed in numerous family of phosphate compounds such as apatite $(\mathrm{Ca}, \mathrm{Sr}, \mathrm{Ba})_{10}\left(\mathrm{PO}_{4}\right)_{6} \mathrm{Cl}_{2}:(\mathrm{Eu}, \mathrm{Mn})[1-3]$ and glaserite $\mathrm{Na}_{2}(\mathrm{Ca}, \mathrm{Sr}, \mathrm{Ba}) \mathrm{Mg}\left(\mathrm{PO}_{4}\right)_{2}$ :(Eu) [4-6]. Inorganic cadmium phosphate $\mathrm{Na}_{2} \mathrm{CdPO}_{4} \mathrm{~F}$ doped by trivalent europium was also recently inves tigated for its optical properties [7].

In the search of new phosphate compounds as host materials for optically active rare earth ions, a close examination of the literature data dedicated to phosphate of sodium and divalent cations $\left(\mathrm{M}^{2+}\right)$ shows that among the large number of reported structures, three of them adopt the general formula $\mathrm{Na}_{2} \mathrm{M}_{5}\left(\mathrm{PO}_{4}\right)_{4}$. Their structural disparities are mainly due to the different coordination numbers adopted by the $\mathrm{M}^{2+}$ cations. $\mathrm{Na}_{2} \mathrm{Ca}_{5}\left(\mathrm{PO}_{4}\right)_{4}[8,9]$ was obtained from hydroxyapatite after high temperature treatments. This compound crystalizes in the hexagonal system with space group $\mathrm{P6}_{1}$,

\footnotetext{
* Corresponding author.

E-mail address: mongi.benamara@fsm.rnu.tn (M. Ben Amara).
}

$a \quad 10.6336 \AA, c \quad 21.6422 \AA$ and $Z \quad 6$. The $a$ and $c$ axes are, respectively, the double and triple of those of the subcell typical of $\alpha$ phases in the $\mathrm{A}_{2} \mathrm{XO}_{4}$ and $\mathrm{ABXO}_{4}$ systems. Authors suggest, for the calcium and sodium atoms, similar environments to those observed in $\mathrm{Ca}_{7}\left(\mathrm{PO}_{4}\right)_{2}\left(\mathrm{SiO}_{4}\right)_{2} . \mathrm{Na}_{2} \mathrm{Mg}_{5}\left(\mathrm{PO}_{4}\right)_{4}[10]$ was prepared at $673 \mathrm{~K}$ in a sealed silver tube under internal pressure of $100 \mathrm{MPa}$. It crystalizes in the triclinic system with space group $\mathrm{P} \overline{1}, a \quad 7.923 \AA, b \quad 8.124 \AA$, c $5.160 \AA, \alpha 90.41^{\circ}, \beta 101.92^{\circ}, \gamma 110.71^{\circ}$ and $Z$ 1. The $\mathrm{Na}_{2} \mathrm{Mg}_{5}\left(\mathrm{PO}_{4}\right)_{4}$ structure is constructed from two types of $\mathrm{MgO}_{6}$ octahedra and one distorted $\mathrm{MgO}_{5}$ polyhedron, connected through two kinds of $\mathrm{PO}_{4}$ tetrahedra. The concomitance of two different coordination numbers ( 5 and 6 ) for magnesium has been reported for other phosphate compounds such as $\mathrm{Mg}_{3}\left(\mathrm{PO}_{4}\right)_{2}$ [11]. $\mathrm{Na}_{2} \mathrm{Zn}_{5}\left(\mathrm{PO}_{4}\right)_{4}$ [12] was obtained as crystals by melt method. This compound crystallizes in the orthorhombic system with space group Pbcn, $a \quad 10.381 \AA, b \quad 8.507 \AA, c \quad 16.568 \AA$ and $Z \quad 4$. The structure exhibits an anionic three dimensional framework built up from $\mathrm{ZnO}_{4}$ and $\mathrm{PO}_{4}$ tetrahedra. The lowest plausible value (4) for the coordination number of $\mathrm{Zn}$ was also observed in several phosphate compounds such as $\mathrm{NaZnPO}_{4}$ [13].

To our knowledge, no similar compound has been reported in the literature for other divalent elements. Thus, as a contribution to the study of the above system, we report here on the synthesis of the sodium cadmium phosphate $\mathrm{Na}_{2} \mathrm{Cd}_{5}\left(\mathrm{PO}_{4}\right)_{4}$. This novel com pound was furthermore characterized by $\mathrm{X}$ ray diffraction, 
vibrational and photoluminescence spectroscopies. The knowledge of the crystal structure of this phase is necessary for a subsequent study of its luminescent properties.

\section{Experimental}

\subsection{Synthesis}

Single crystals of $\mathrm{Na}_{2} \mathrm{Cd}_{5}\left(\mathrm{PO}_{4}\right)_{4}$ were grown in a flux of sodium dimolybdate $\mathrm{Na}_{2} \mathrm{Mo}_{2} \mathrm{O}_{7}$ with an atomic ratio P:Mo 2:1. Appro priate amounts of $\mathrm{Na}_{2} \mathrm{CO}_{3}, \mathrm{Cd}\left(\mathrm{NO}_{3}\right)_{2} \cdot 4 \mathrm{H}_{2} \mathrm{O},\left(\mathrm{NH}_{4}\right) \mathrm{H}_{2} \mathrm{PO}_{4}$ and $\mathrm{H}_{24} \mathrm{~N}_{6} \mathrm{Mo}_{7} \mathrm{O}_{24}$ were dissolved in concentrated nitric acid and the derived solution was heated to dryness at $373 \mathrm{~K}$. The resulting dry residue was ground in an agate mortar, transferred into a platinum crucible and heated at $873 \mathrm{~K}$ for $24 \mathrm{~h}$ until the decomposition products $\left(\mathrm{NH}_{3}, \mathrm{CO}_{2}\right)$ were removed. After being finely ground, the mixture was melted for $1 \mathrm{~h}$ at $1173 \mathrm{~K}$ before being slowly cooled at a rate of $10^{\circ} . \mathrm{h}^{-1}$ down to $673 \mathrm{~K}$, and then brought back to room temperature. The mixture, obtained by washing the final product with warm water in order to dissolve the flux, consists of essentially colorless and quasi prismatic single crystals.

A polycrystalline sample of the title compound was successfully synthesized by the Pechini method [14]. The preparation was un dertaken in the following steps (1): $0.213 \mathrm{~g}$ of $\mathrm{NaCO}_{3}, 3.116 \mathrm{~g}$ of $\mathrm{Cd}\left(\mathrm{NO}_{3}\right)_{2} \cdot 4 \mathrm{H}_{2} \mathrm{O}$ and $1.067 \mathrm{~g}$ of $\left(\mathrm{NH}_{4}\right)_{2} \mathrm{HPO}_{4}$ were dissolved in diluted nitric acid. (2): $0.22 \mathrm{~g}$ of critic acid and $0.1 \mathrm{~g}$ of ethylene glycol were added to the obtained solution. (3): the limpid solution was kept at $373 \mathrm{~K}$ for $8 \mathrm{~h}$ under continuous stirring. (4): The transparent gel was heated at $423 \mathrm{~K}$ leading to a brown resin. (5): A white powder was obtained by calcining the precursor for $12 \mathrm{~h}$ successively at $673 \mathrm{~K}$ and $873 \mathrm{~K}$, then for $24 \mathrm{~h}$ at $1173 \mathrm{~K}$.

\section{2. $X$ ray diffraction}

The purity of the synthesized powder was examined through its $X$ ray diagram collected in the range $5^{\circ} \leq 2 \theta \leq 120^{\circ}$ on a PANatycal diffractometer using $\mathrm{Cu}(\mathrm{K} \alpha)$ radiation ( $\lambda$ 1.5406 $\AA$ ) (Fig. 1).
The structure was determined by $\mathrm{X}$ ray diffraction performed on a crystal of dimensions $0.07 \times 0.14 \times 0.22 \mathrm{~mm}^{3}$. Data collection was recorded by a CAD4 Enraf Nonius X ray diffractometer using a graphite monochromated MoK $\alpha$ radiation $(\lambda \quad 0.71073 \AA$ ). The unit cell parameters and the orientation matrix were determined on the basis of 25 intense reflections in the range $9.41^{\circ} \leq \theta \leq 14.03^{\circ}$. A total of 1462 unique reflections were collected with a maximum $2 \theta$ of $54^{\circ}\left(R_{\text {int }} \quad 0.059\right)$ using the $\omega 2 \theta$ scan mode. Only 1163 re flections were considered observed according to the criterion $[\mathrm{I}>2 \sigma(\mathrm{I})]$. The intensity data were corrected for the Lorentz and polarization effects and then for absorption by the empirical method using DIFABS program ( $\left.T_{\min , \max } \quad 0.28,0.56\right)$ [15]. On the basis of systematic absences and statistic of intensity distribution, the space group was determined to be $\mathrm{P} 21_{1} / \mathrm{a}$.

The structure was solved by direct method using SIR 92 pro gram [16] which revealed the positions of the cadmium atoms. The remaining atomic positions were located by Fourier synthesis alternating with least squares refinement based on $F^{2}$ (SHELXL 97) [17]. A possible disordered distribution of $\mathrm{Cd}^{2+}$ and $\mathrm{Na}^{+}$in $\mathrm{M}(1)$ and $\mathrm{M}(2)$ sites was considered due to their similar ionic radii $\left(r\left(\mathrm{Cd}^{2+}\right) \quad 0.95 \AA\right.$ and $r\left(\mathrm{Na}^{+}\right) \quad 1.02 \AA$ [18]. The refinements based on this hypothesis converged to a distribution in $\mathrm{M}(1)$ and $\mathrm{M}(2)$ sites close to the atomic ratios of $\mathrm{Cd}: \mathrm{Na} \quad 1: 3$ and 3:1, respectively. The occupancy factors of $\mathrm{Cd}$ and $\mathrm{Na}$ atoms in the considered sites were then fixed to $(0.25 \mathrm{Cd}+0.75 \mathrm{Na})$ and $(0.75 \mathrm{Cd}+0.25 \mathrm{Na})$, respectively. A last refinement, including all atomic coordinates and anisotropic thermal parameters, converged at $R_{1} \quad 0.036$ and $\mathrm{w} R_{2} \quad 0.086$ for the observed reflections, which confirms conse quently the proposed formula. Crystal data, experimental condi tions for intensity measurement, and refinement parameters are given in Table 1. Final atomic coordinates and equivalent isotropic temperature factors are reported in Table 2 and selected bond distances in Table 3. All calculations were performed using the Wingx software package [19].

Further details of the crystal structure investigation may be obtained from the Fachinformationszentrum Karlsruhe, D 76344 Eggenstein Leopoldshafen (Germany), on quoting the depository

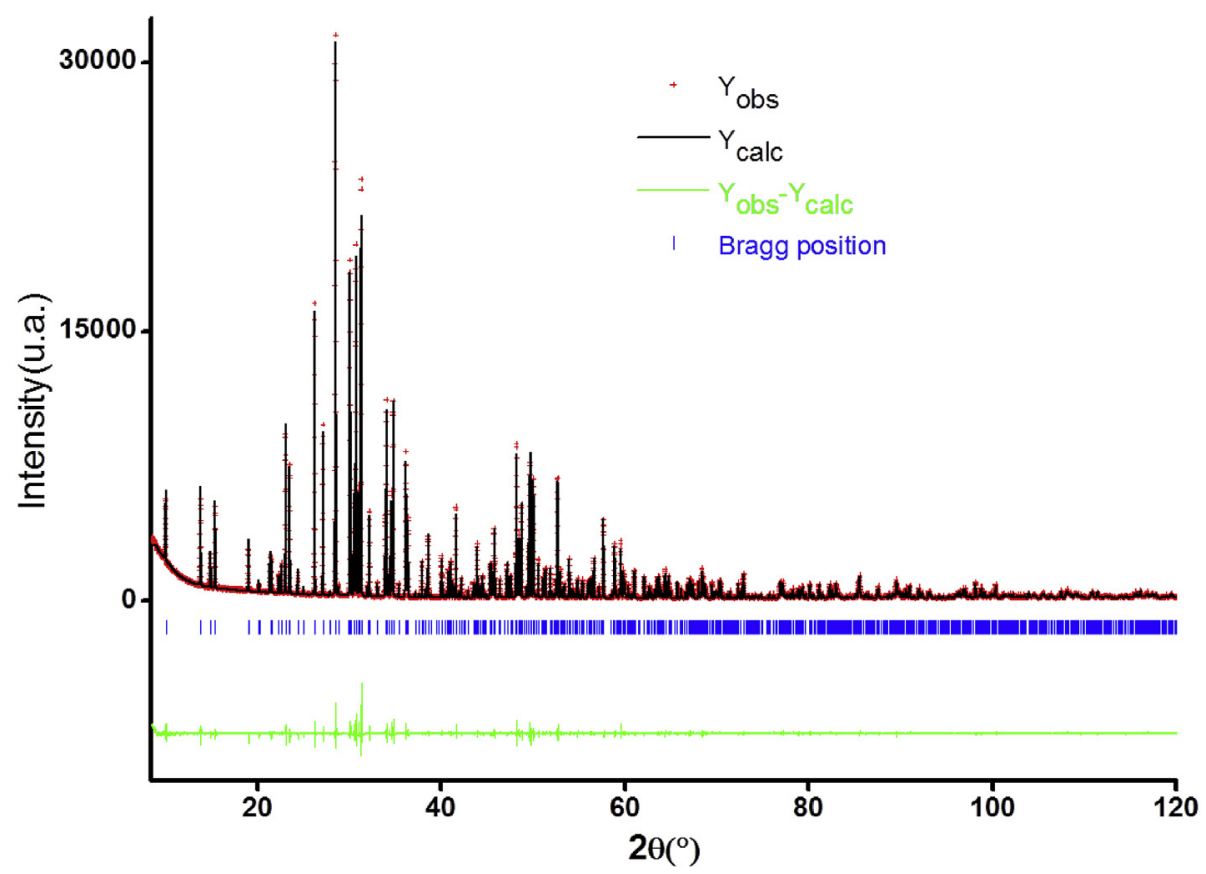

Fig. 1. X-ray powder diffraction pattern of $\mathrm{Na}_{2} \mathrm{Cd}_{5}\left(\mathrm{PO}_{4}\right)_{4}$. 
Table 1

Details of the data collection and structural refinement for $\mathrm{Na}_{2} \mathrm{Cd}_{5}\left(\mathrm{PO}_{4}\right)_{4}$.

\begin{tabular}{|c|c|}
\hline \multicolumn{2}{|l|}{ Crystal data } \\
\hline Chemical formula & $\mathrm{Na}_{2} \mathrm{Cd}_{5}\left(\mathrm{PO}_{4}\right)_{4}$ \\
\hline Formula weight (g/mol) & 987.86 \\
\hline Crystal system & Monoclinic \\
\hline Space group & $\mathrm{P} 21 / \mathrm{a}$ \\
\hline$a(\AA)$ & $8.276(1)$ \\
\hline$b(\AA)$ & $9.301(3)$ \\
\hline$c(\AA)$ & $9.455(2)$ \\
\hline$\beta\left({ }^{\circ}\right)$ & $111.82(1)$ \\
\hline$V\left(\AA^{3}\right)$ & 675.66 \\
\hline$Z$ & 2 \\
\hline$\rho_{\text {cal }}\left(\mathrm{Kg} / \mathrm{m}^{3}\right)$ & $4.86 \times 10^{3}$ \\
\hline \multicolumn{2}{|l|}{ Intensity measurements } \\
\hline Crystal dimensions (mm) & $0.07 \times 0.14 \times 0.22$ \\
\hline Temperature $(\mathrm{K})$ & $293(2)$ \\
\hline Apparatus & CAD4 (Enraf-Nonius) \\
\hline$\lambda \operatorname{MoK} \alpha(\AA)$ & 0.71073 \\
\hline Monochromator & Graphite \\
\hline$\mu\left(\mathrm{mm}^{1}\right)$ & 8.375 \\
\hline Scan mode & $\omega / 2 \theta$ \\
\hline$\theta$ range & $2,32 \leq \theta \leq 26,97$ \\
\hline Unique reflections; $R_{i n t}$ & $1462 ; 0.059$ \\
\hline Observed reflections $(I>2 \sigma(I))$ & 1163 \\
\hline Indices & $-1 \leq h \leq 10 ;-1 \leq k \leq 11 ;-12 \leq l \leq 12$ \\
\hline$F(000)$ & $900--c---10$ \\
\hline \multicolumn{2}{|l|}{ Structure solution and refinement } \\
\hline Intensity correction & Lorentz-Polarization \\
\hline Absorption correction & Refdelf \\
\hline$T_{\min ; \max }$ & $0.28 ; 0.56$ \\
\hline Resolution method & Direct method \\
\hline Agreement factors $(I>2 \sigma(I))$ & $R_{1} \quad 0.036 ; \mathrm{w} R_{2} \quad 0.086 ; S \quad 1.06$ \\
\hline Number of refined parameters & 124 \\
\hline Extinction coefficient & $0.0037(7)$ \\
\hline Weighting scheme & W $1 /\left[\sigma^{2}\left(F_{o}^{2}\right)+(0.0470 P)^{2}+0.419 P\right]$ where $P \quad\left(F_{o}^{2}+2 F_{c}^{2}\right) / 3$ \\
\hline$(\Delta \rho)_{\max ; \min }\left(\mathrm{e} . \AA^{3}\right)$ & $1.536 ;-1.397$ \\
\hline
\end{tabular}

number CSD 433733.

In order to confirm the proposed cationic distribution, the final structural model was examined with bond valence sum (BVS) cal culations using Chardi (CD) method [20]. The charge distribution was calculated using the CHARDI IT program [21]. The corre sponding results are reported in Table 4. This method was used to validate structures, as in the case where some atoms are disordered in the same crystallographic site [22]. In the present structure, the calculated valences of all the sites are consistent with their formal charges. In particular, the valence of 1.239 and 1.729 calculated for the $\mathrm{M}(1)$ and $\mathrm{M}(2)$ sites, respectively, are in a good agreement with 1.25 and 1.75 predicted by the structural refinement.

Table 2

Atomic coordinates and equivalent thermal parameters $U_{\text {eq }}\left(\AA^{2}\right)$ for $\mathrm{Na}_{2} \mathrm{Cd}_{5}\left(\mathrm{PO}_{4}\right)_{4}$.

\begin{tabular}{llllll}
\hline Site & Atom & $x(\sigma)$ & $y(\sigma)$ & $z(\sigma)$ & $U_{e q}(\sigma)^{\mathrm{a}}$ \\
\hline $\mathrm{M}(1)$ & $3 / 4 \mathrm{Na}+1 / 4 \mathrm{Cd}$ & $0.3258(2)$ & $0.1339(2)$ & $0.8926(2)$ & $0.0144(3)$ \\
$\mathrm{M}(2)$ & $1 / 4 \mathrm{Na}+3 / 4 \mathrm{Cd}$ & $0.5365(1)$ & $0.9958(1)$ & $0.6881(1)$ & $0.0103(2)$ \\
$\mathrm{Cd}(1)$ & $\mathrm{Cd}$ & $0.4517(1)$ & $0.6460(1)$ & $0.5983(1)$ & $0.0128(2)$ \\
$\mathrm{Cd}(2)$ & $\mathrm{Cd}$ & 0 & 0 & 0 & $0.0107(2)$ \\
$\mathrm{P}(1)$ & $\mathrm{P}$ & $0.3085(2)$ & $0.3328(2)$ & $0.6370(2)$ & $0.0069(4)$ \\
$\mathrm{O}(11)$ & $\mathrm{O}$ & $0.3738(7)$ & $0.8645(6)$ & $0.4858(6)$ & $0.0114(11)$ \\
$\mathrm{O}(12)$ & $\mathrm{O}$ & $0.4499(7)$ & $0.4077(7)$ & $0.5961(7)$ & $0.0129(11)$ \\
$\mathrm{O}(13)$ & $\mathrm{O}$ & $0.8024(7)$ & $0.1076(6)$ & $0.7890(6)$ & $0.0105(11)$ \\
$\mathrm{O}(14)$ & $\mathrm{O}$ & $0.3308(7)$ & $0.1690(6)$ & $0.6468(6)$ & $0.0119(12)$ \\
$\mathrm{P}(2)$ & $\mathrm{P}$ & $0.2994(2)$ & $0.8030(2)$ & $0.8545(2)$ & $0.0071(4)$ \\
$\mathrm{O}(21)$ & $\mathrm{O}$ & $0.2380(7)$ & $0.7114(7)$ & $0.7071(6)$ & $0.0135(12)$ \\
$\mathrm{O}(22)$ & $\mathrm{O}$ & $0.6463(8)$ & $0.6010(7)$ & $0.8527(7)$ & $0.0186(13)$ \\
$\mathrm{O}(23)$ & $\mathrm{O}$ & $0.4527(7)$ & $0.9011(7)$ & $0.8624(6)$ & $0.0154(12)$ \\
$\mathrm{O}(24)$ & $\mathrm{O}$ & $0.3594(7)$ & $0.7045(7)$ & $0.9949(6)$ & $0.0131(12)$ \\
\hline
\end{tabular}

\footnotetext{
a $U e q$ is defined as one third of the trace of the orthogonalized Uij tensor.
}

\subsection{Vibrational spectroscopy}

The Raman scattering experiments were carried out on a multichannel X-Y Dilor spectrometer using the $514.5 \mathrm{~nm}$ line of a Spectra Physics argon ion laser. The Raman spectrum was recorded at room temperature in the wavenumber range $60-4000 \mathrm{~cm}^{-1}$ with resolution of about $2 \mathrm{~cm}^{-1}$. Infrared spectrum was obtained at room temperature by the $\mathrm{KBr}$ pellet method in the spectral range of $400-4000 \mathrm{~cm}^{-1}$ using a BioRad 575C FT IR spectrometer. The spectral resolution was about $3 \mathrm{~cm}^{-1}$.

\subsection{Photoluminescence}

Photoluminescence properties were analyzed using a spectro fluorimeter SPEX FL212. Excitation spectra were corrected for the variation of the incident flux as well as emission spectra for the transmission of the monochromator and the response of the pho tomultiplier. This equipment is composed of a $450 \mathrm{~W}$ xenon lamp, an excitation double monochromator, a sample holder, an emission double monochromator and a photomultiplier tube.

\section{Results and discussion}

\subsection{Description of the structure}

Atomic representation of asymmetric unit and projection of the structure on the (100) plane are given in Fig. 2a and b, respectively. The structure of $\mathrm{Na}_{2} \mathrm{Cd}_{5}\left(\mathrm{PO}_{4}\right)_{4}$ can be described as a three dimensional network of $\mathrm{CdO}_{\mathrm{x}}$ and $\mathrm{MO}_{\mathrm{x}}$ polyhedra $(\mathrm{M} \quad \mathrm{Na}$ or $\mathrm{Cd}$ and $x \quad 6$ or 7 ) linked together through the $\mathrm{PO}_{4}$ tetrahedra. From the projection of the structure along the $\mathrm{b}$ axis (Fig. 3), one can 
Table 3

Selected interatomic distances $(\AA)$ and angles $\left(^{\circ}\right)$ for $\mathrm{Na}_{2} \mathrm{Cd}_{5}\left(\mathrm{PO}_{4}\right)_{4}$.

\begin{tabular}{|c|c|c|c|}
\hline \multicolumn{4}{|l|}{$\mathrm{PO}_{4}$ tetrahedra } \\
\hline $\mathrm{P}(1) \quad \mathrm{O}(11)$ & $1.552(5)$ & $\mathrm{P}(2) \quad \mathrm{O}(21)$ & $1.549(6)$ \\
\hline $\mathrm{P}(1) \quad \mathrm{O}(12)$ & $1.530(6)$ & $\mathrm{P}(2) \quad \mathrm{O}(22)$ & $1.544(6)$ \\
\hline $\mathrm{P}(1) \quad \mathrm{O}(13)$ & $1.558(5)$ & $\mathrm{P}(2) \quad \mathrm{O}(23)$ & $1.542(6)$ \\
\hline $\mathrm{P}(1) \quad \mathrm{O}(14)$ & $1.533(6)$ & $\mathrm{P}(2) \quad \mathrm{O}(24)$ & $1.536(6)$ \\
\hline$\langle P(1)-O\rangle$ & 1.543 & $<P(2)-O>$ & 1.543 \\
\hline$D I(P O)$ & 0.0101 & & 0.0049 \\
\hline $\mathrm{O}(12)-\mathrm{P}(1)-\mathrm{O}(14)$ & $112.4(3)$ & $\mathrm{O}(23)-\mathrm{P}(2)-\mathrm{O}(21)$ & $111.0(3)$ \\
\hline $\mathrm{O}(12)-\mathrm{P}(1)-\mathrm{O}(13)$ & $111.1(3)$ & $\mathrm{O}(24)-\mathrm{P}(2)-\mathrm{O}(22)$ & $110.8(3)$ \\
\hline $\mathrm{O}(12)-\mathrm{P}(1)-\mathrm{O}(11)$ & $110.3(3)$ & $\mathrm{O}(24)-\mathrm{P}(2)-\mathrm{O}(21)$ & $110.0(3)$ \\
\hline $\mathrm{O}(14)-\mathrm{P}(1)-\mathrm{O}(13)$ & $110.0(3)$ & $\mathrm{O}(24)-\mathrm{P}(2)-\mathrm{O}(23)$ & $108.4(3)$ \\
\hline $\mathrm{O}(14)-\mathrm{P}(1)-\mathrm{O}(11)$ & 107.2(3) & $\mathrm{O}(23)-\mathrm{P}(2)-\mathrm{O}(22)$ & $108.4(4)$ \\
\hline $\mathrm{O}(11)-\mathrm{P}(1)-\mathrm{O}(13)$ & $105.5(3)$ & $\mathrm{O}(22)-\mathrm{P}(2)-\mathrm{O}(21)$ & $108.3(3)$ \\
\hline$<O-P(1)-O>$ & 109.42 & $<O-P(2)-O>$ & 109.48 \\
\hline $\mathrm{DI}(\mathrm{OPO})$ & 0.0185 & & 0.0110 \\
\hline \multicolumn{2}{|l|}{$\mathrm{M}(1) \mathrm{O}_{7}$ polyhedron } & \multicolumn{2}{|l|}{$\mathrm{M}(2) \mathrm{O}_{6}$ polyhedron } \\
\hline $\mathrm{M}(1)-\mathrm{O}(24)$ & $2.263(6)$ & $\mathrm{M}(2)-\mathrm{O}(23)$ & $2.196(6)$ \\
\hline $\mathrm{M}(1)-\mathrm{O}(14)$ & $2.363(6)$ & $\mathrm{M}(2)-\mathrm{O}(11)$ & $2.247(5)$ \\
\hline $\mathrm{M}(1)-\mathrm{O}(23)$ & $2.382(6)$ & $\mathrm{M}(2)-\mathrm{O}(14)$ & $2.270(5)$ \\
\hline $\mathrm{M}(1)-\mathrm{O}(23)$ & $2.469(7)$ & $\mathrm{M}(2)-\mathrm{O}(13)$ & $2.297(6)$ \\
\hline $\mathrm{M}(1)-\mathrm{O}(13)$ & $2.577(6)$ & $\mathrm{M}(2)-\mathrm{O}(11)$ & $2.418(5)$ \\
\hline $\mathrm{M}(1)-\mathrm{O}(22)$ & $2.589(7)$ & $\mathrm{M}(2)-\mathrm{O}(21)$ & $2.511(6)$ \\
\hline $\mathrm{M}(1)-\mathrm{O}(24)$ & $2.850(6)$ & & \\
\hline$<M(1)-O>$ & 2.499 & $<M(2)-O>$ & 2.323 \\
\hline $\mathrm{DI}(\mathrm{MO})$ & 0.0606 & & 0.0401 \\
\hline \multicolumn{2}{|l|}{$\mathrm{Cd}(1) \mathrm{O}_{7}$ polyhedron } & \multicolumn{2}{|l|}{$\mathrm{Cd}(2) \mathrm{O}_{6}$ polyhedron } \\
\hline $\mathrm{Cd}(1) \quad \mathrm{O}(12)$ & $2.216(6)$ & $\mathrm{Cd}(2) \quad \mathrm{O}(24) \times 2$ & $2.221(6)$ \\
\hline $\mathrm{Cd}(1) \quad \mathrm{O}(11)$ & $2.273(6)$ & $\mathrm{Cd}(2) \quad \mathrm{O}(13) \times 2$ & $2.287(5)$ \\
\hline $\mathrm{Cd}(1) \quad \mathrm{O}(12)$ & $2.325(6)$ & $\mathrm{Cd}(2)-\mathrm{O}(22 \times 2$ & $2.355(6)$ \\
\hline $\mathrm{Cd}(1) \quad \mathrm{O}(22)$ & $2.382(6)$ & & \\
\hline $\mathrm{Cd}(1) \quad \mathrm{O}(21)$ & $2.430(6)$ & & \\
\hline $\mathrm{Cd}(1) \quad \mathrm{O}(21)$ & $2.573(6)$ & & \\
\hline $\mathrm{Cd}(1) \quad \mathrm{O}(14)$ & $2.618(6)$ & & \\
\hline$<C d(1)-O>$ & 2.402 & $<C d(2)-O>$ & 2.288 \\
\hline$D I(M O)$ & 0.0547 & & 0.0204 \\
\hline \multicolumn{4}{|c|}{ distortion indices: $\mathrm{DI}(\mathrm{PO}) \quad\left(\sum_{i}^{4}\left|P O_{i}-P O_{m}\right|\right) / 4 P O_{m}$} \\
\hline \multicolumn{4}{|c|}{$\mathrm{DI}(\mathrm{OPO}) \quad\left(\sum_{i=1}^{6}\left|O P O_{i}-\mathrm{OPO}_{m}\right|\right) / 6 O P O_{m}$} \\
\hline
\end{tabular}

formally isolate cationic polyhedra layers stacked parallel to the plane (20-3). Two successive layers equivalent by the a glide plane perpendicular to the $\mathrm{b}$ axis are interconnected via the $\mathrm{PO}_{4}$ tetra hedra. One layer is depicted separately in Fig. 4, it consists of an alternating assemblage of two kinds of chains both propagating along the $b$ axis. The $\left[\mathrm{M}(2) \mathrm{Cd}(1) \mathrm{O}_{11}\right]_{\infty}$ chains are formed by alter nating $\mathrm{Cd}(1) \mathrm{O}_{7}$ and $\mathrm{M}(2) \mathrm{O}_{6}$ polyhedra sharing common corners and edges. The $\left[\mathrm{M}(1)_{2} \mathrm{Cd}(2) \mathrm{O}_{16}\right]_{\infty}$ chains are consisted by $\mathrm{M}(1)_{2} \mathrm{O}_{12}$ units of edge sharing $\mathrm{M}(1) \mathrm{O}_{7}$ polyhedra, which are connected to

Table 4

Charge distribution (CD) sum calculation of $\mathrm{Na}_{2} \mathrm{Cd}_{5}\left(\mathrm{PO}_{4}\right)_{4}$.

\begin{tabular}{llllll}
\hline Cation & $q$ & $Q$ & Anion & $q$ & $Q$ \\
\hline $\mathrm{M}(1)$ & 1.250 & 1.239 & $\mathrm{O}(11)$ & -2.000 & -2.145 \\
$\mathrm{M}(2)$ & 1.750 & 1.729 & $\mathrm{O}(12)$ & -2.000 & -2.098 \\
$\mathrm{Cd}(1)$ & 2.000 & 2.000 & $\mathrm{O}(13)$ & -2.000 & -1.930 \\
$\mathrm{Cd}(2)$ & 2.000 & 2.025 & $\mathrm{O}(14)$ & -2.000 & -2.021 \\
$\mathrm{P}(1)$ & 5.000 & 4.886 & $\mathrm{O}(21)$ & -2.000 & -1.778 \\
$\mathrm{P}(2)$ & 5.000 & 5.134 & $\mathrm{O}(22)$ & -2.000 & -1.930 \\
& & & $\mathrm{O}(23)$ & -2.000 & -2.050 \\
$\sigma \quad 0.080 \sigma$ & 0.117 & & $\mathrm{O}(24)$ & -2.000 & -2.049
\end{tabular}

Q: computed charge; $q$ : formal oxidation number;

Charge dispersion: $\sigma \quad \sum_{i=1}^{n}\left[\left(q_{i}-Q_{i}\right)^{2} / N-1\right]^{1 / 2}$

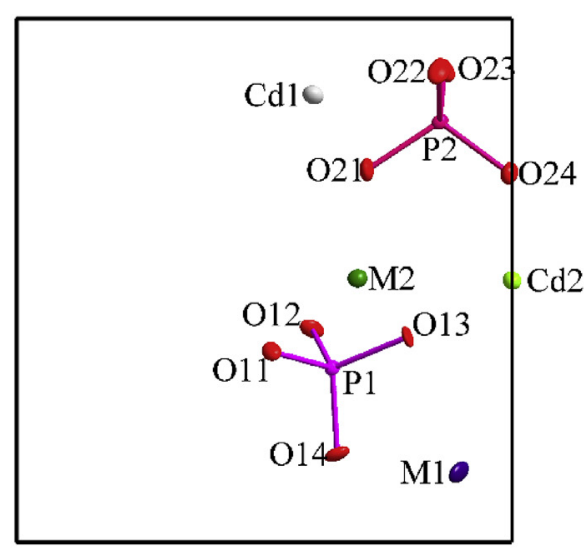

(a)

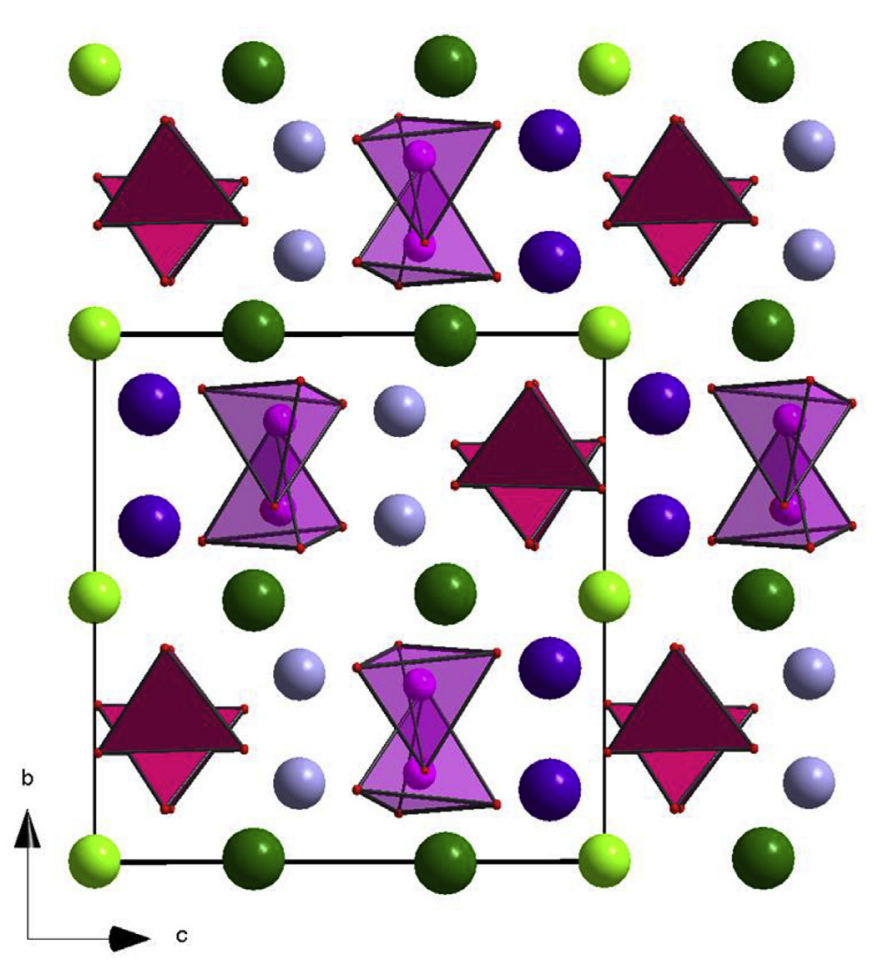

(b)

Fig. 2. (a) Atomic representation of asymmetric unit (b) Projection of the $\mathrm{Na}_{2} \mathrm{Cd}_{5}\left(\mathrm{PO}_{4}\right)_{4}$ structure along the [100] direction $(\mathrm{M}(1)$ : violet; $\mathrm{M}(2)$ : olive; $\mathrm{Cd}(1)$ : mauve; $\mathrm{Cd}(2)$ : Green; $\mathrm{P}(1) \mathrm{O}_{4}$ : purple; $\mathrm{P}(2) \mathrm{O}_{4}$ pink).

$\mathrm{Cd}(2) \mathrm{O}_{6}$ octahedra through common edges. Thereby, although the framework is highly complex, it can be easily described by considering that all the $\mathrm{CdO}_{\mathrm{x}}$ and $\mathrm{MO}_{\mathrm{x}}$ polyhedra are linked directly by sharing either corners or edges to form $\mathrm{M}(1)_{2} \mathrm{M}(2)_{2} \mathrm{Cd}_{3} \mathrm{O}_{16}$ units connected to each other either directly or through $\mathrm{PO}_{4}$ tetrahedra and leading to the formation of a compact structure.

Considering cadmium-oxygen distances below $3.0 \AA$ as sug gested by Donnay and Allmann [23], the $\mathrm{Cd}(1)$ and $\mathrm{Cd}(2)$ sites are surrounded by seven and six oxygen atoms (Fig. 5) with $\mathrm{Cd}-\mathrm{O}$ distances ranging from 2.216(6) $\AA$ to 2.618(6) $\AA$ and from 2.221(6) $\AA$ to $2.355(6) \AA$, respectively. These distances are closer to those found in the interstitial voids of the $\mathrm{NaCd}_{4}\left(\mathrm{PO}_{4}\right)_{3}(2.186-2.462$ and 2.230 to $2.421 \AA$ ) [24] than to the $\mathrm{Cd}-\mathrm{O}$ distances in the polyhedral 


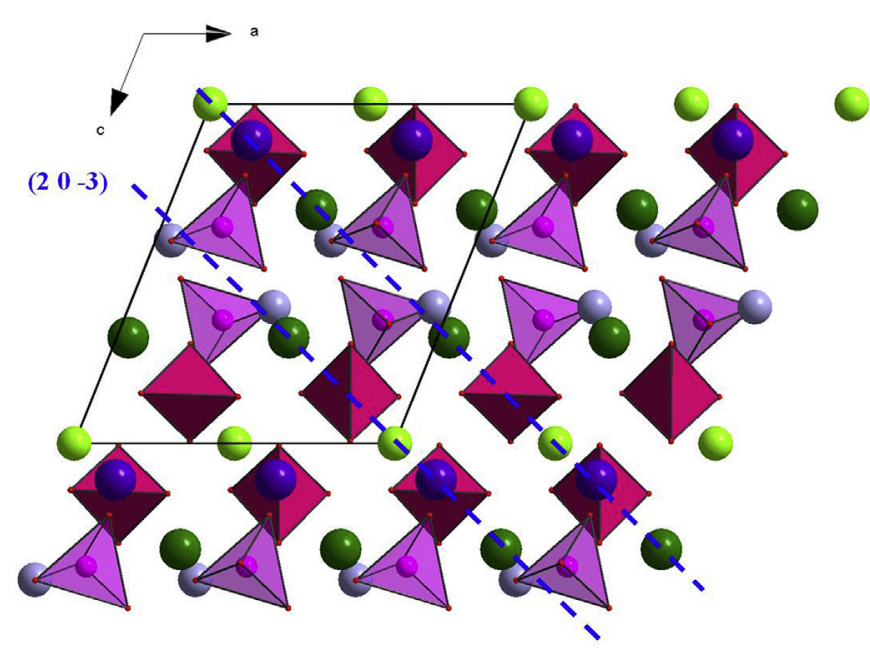

Fig. 3. Projection of the $\mathrm{Na}_{2} \mathrm{Cd}_{5}\left(\mathrm{PO}_{4}\right)_{4}$ structure along the [010] direction ( $\mathrm{M}(1)$ : violet; $\mathrm{M}(2)$ : olive; $\mathrm{Cd}(1)$ : mauve; $\mathrm{Cd}(2)$ : Green; $\mathrm{P}(1) \mathrm{O}_{4}$ : purple; $\mathrm{P}(2) \mathrm{O}_{4}$ pink).

cluster $\left[\mathrm{Cd}_{2}\left(\mathrm{VO}_{4}\right)_{3}\right]^{5-}$ observed in $\mathrm{KCd}_{4}\left(\mathrm{VO}_{4}\right)_{3}(2.150-2.362$ and 2.154 to $2.303 \AA$ ) [25].

Because $M(2)$ site is statistically occupied by $(3 / 4 \mathrm{Cd}+1 / 4 \mathrm{Na})$, the average bond length $\langle\mathrm{M}(2) \mathrm{O}\rangle \quad 2.323 \AA$ is much closer to $2.310 \AA$ than to $2.40 \AA$ observed for the six coordinated $\mathrm{Cd}$ and $\mathrm{Na}$ atoms in $\mathrm{NaCdPO}_{4}$, respectively [26]. The M(1) site is also statisti cally occupied by $\mathrm{Cd}$ and $\mathrm{Na}$, with atomic ratio $\mathrm{Cd}: \mathrm{Na} 1: 3$. Furthermore, this site has a $[6+1]$ coordination, with six short distances between $2.263 \AA$ and $2.589 \AA$ and a long distance of $2.850 \AA$. As a consequence, the mean distance $<\mathrm{M}(1) \mathrm{O}>2.499 \AA$ is larger than observed within $\mathrm{M}(2)$ site.

The $\mathrm{P}(1) \mathrm{O}_{4}$ and $\mathrm{P}(2) \mathrm{O}_{4}$ tetrahedra present $\mathrm{P}-\mathrm{O}$ distances included between 1.530(6) and 1.558(5) Å. Their mean distances $\langle\mathrm{P}(1)-\mathrm{O}\rangle \quad\langle\mathrm{P}(2)-\mathrm{O}\rangle \quad 1.543 \AA$ are consistent with that pre dicted by Baur and in a good accordance with those usually observed in monophosphate groups [27-29]. The minimum, maximum and average tetrahedral $\mathrm{O}-\mathrm{P}-\mathrm{O}$ angles are respectively: $\mathrm{O}-\mathrm{P}(1) \mathrm{O} \quad 105.5,112.4$ and $109.42^{\circ}$; $\mathrm{O}-\mathrm{P}(2) \mathrm{O} \quad 108.3,111.0$ and $109.48^{\circ}$. This dispersion reflects that the $\mathrm{P}(1) \mathrm{O}_{4}$ tetrahedron is more distorted than the $\mathrm{P}(2) \mathrm{O}_{4}$ one. The difference in the cationic distribution around the two tetrahedra (Fig. 6) seems to be corre lated with the disparity between their distortions. The calculated distortion indices corroborate this result as shown in Table 3.

The main feature of this structure is the existence of different kinds of sites for cadmium and sodium atoms. The $\mathrm{Cd}(1)$ and $\mathrm{Cd}(2)$ sites are full occupied by cadmium atoms whereas the $\mathrm{M}(1)$ and $\mathrm{M}(2)$ sites are statistically occupied by sodium and cadmium atoms. The cadmium atoms have slightly distorted octahedral environ ments in $\mathrm{Cd}(2)$ and $\mathrm{M}(2)$ sites, while their environments consist of seven oxygen atoms in the $\mathrm{Cd}(1)$ and $\mathrm{M}(1)$ sites. This cationic dis tribution is very different from those reported for phosphates with similar composition. Indeed, $\mathrm{Na}_{2} \mathrm{Mg}_{5}\left(\mathrm{PO}_{4}\right)_{4}$ adopts the triclinic system with space group $\mathrm{P} \overline{1}$. Its structure consists of a three dimensional framework built up from two kinds of $\mathrm{MgO}_{6}$ octa hedra and one distorted $\mathrm{MgO}_{5}$ polyhedron sharing edges and cor ners and linked to each other through the $\mathrm{PO}_{4}$ tetrahedra [10]. $\mathrm{Na}_{2} \mathrm{Ca}_{5}\left(\mathrm{PO}_{4}\right)_{4}$ is a member of the nagelschmidtite compounds family which crystallizes in the hexagonal system with space group $\mathrm{P}_{1}$. Its structure involves $\mathrm{NaO}_{9}, \mathrm{CaO}_{\mathrm{x}}$ and $(\mathrm{Na}, \mathrm{Ca}) \mathrm{O}_{\mathrm{x}}(\mathrm{x}$ 6-8) polyhedra linked together through the monophosphate groups [9]. $\mathrm{Na}_{2} \mathrm{Zn}_{5}\left(\mathrm{PO}_{4}\right)_{4}$ crystallizes in the orthorhombic system with space group $\mathrm{Pbcn}$. Its structure is made up of five types of tetrahedra, three $\mathrm{ZnO}_{4}$ and two $\mathrm{PO}_{4}$, linked to each other by only shared cor ners to form a three dimensional anionic framework [12].

\subsection{Vibrational analysis}

The $\mathrm{Na}_{2} \mathrm{Cd}_{5}\left(\mathrm{PO}_{4}\right)_{4}$ structure belongs to the spectroscopic group $\mathrm{C}_{2 \mathrm{~h}}$. The primitive cell is centrosymmetric containing two formula units. Two cadmium atoms as well as all phosphorus, oxygen and sodium ones are located on the general $4 \mathrm{e}$ position ( $C_{1}$ symmetry); whereas the remainder of cadmium atoms occupies the 2 a position

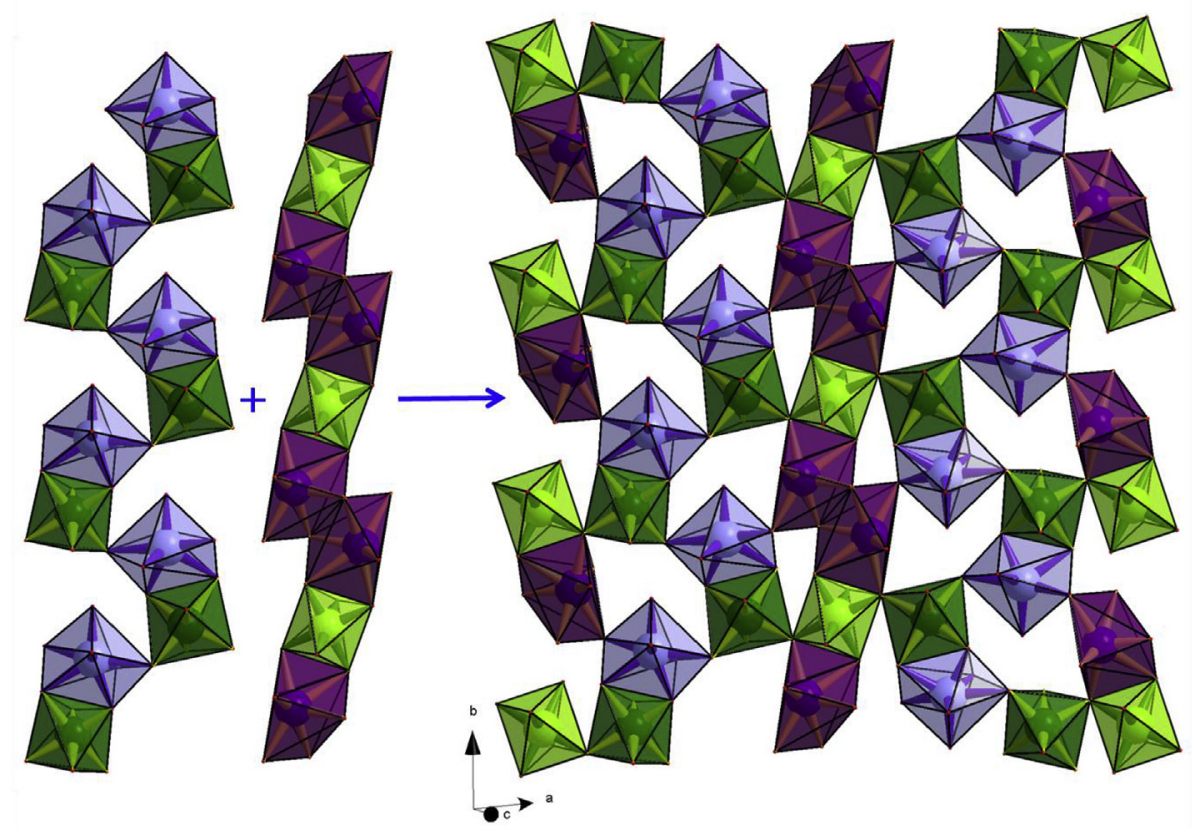

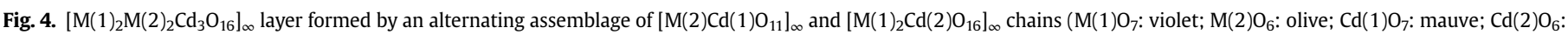
Green). 

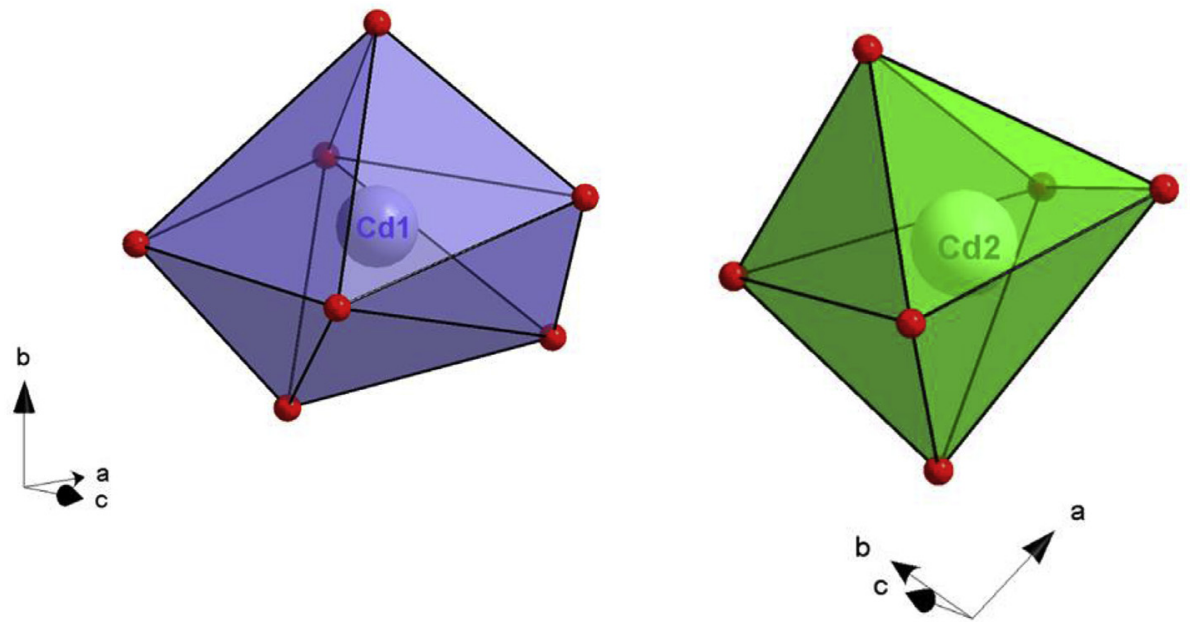

Fig. 5. Oxygen environments of the cadmium atoms in the $\mathrm{Na}_{2} \mathrm{Cd}_{5}\left(\mathrm{PO}_{4}\right)_{4}$ structure $\left(\mathrm{Cd}(1) \mathrm{O}_{7}\right.$ : mauve; $\mathrm{Cd}(2) \mathrm{O}_{6}$ : Green)
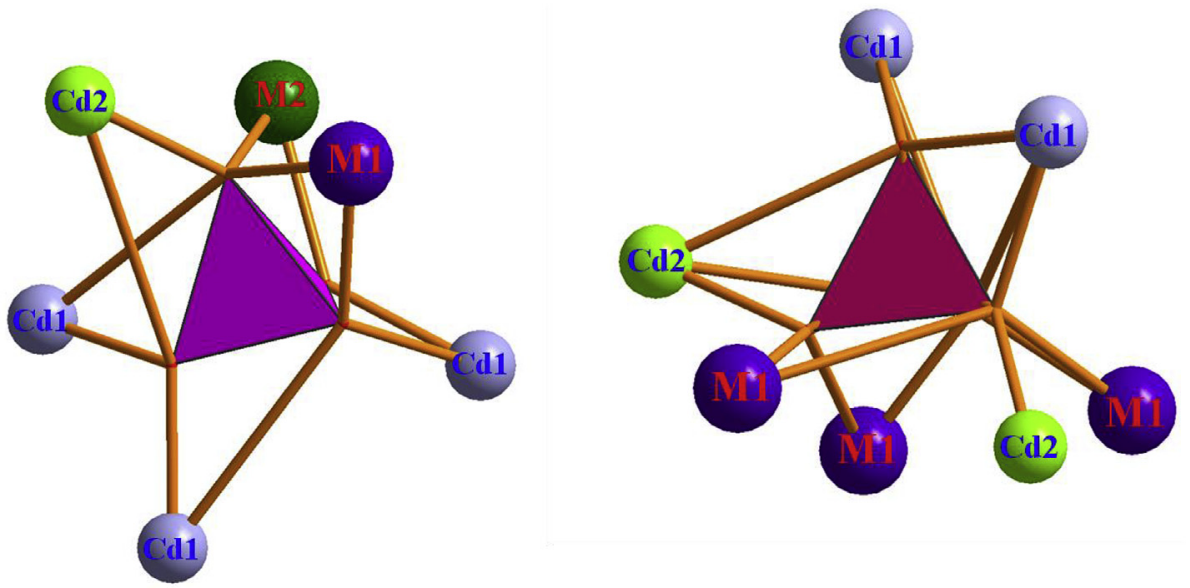

Fig. 6. Cationic environments of the $\mathrm{P}(1) \mathrm{O}_{4}$ (left) and $\mathrm{P}(2) \mathrm{O}_{4}$ (right) tetrahedra in $\mathrm{Na}_{2} \mathrm{Cd}_{5}\left(\mathrm{PO}_{4}\right)_{4}$ for maximum distance $\mathrm{d}(\mathrm{P}-\mathrm{M}) \quad 3.30 \AA$.

( $\mathrm{C}_{\mathrm{i}}$ symmetry). The $\mathrm{Na}_{2} \mathrm{Cd}_{5}\left(\mathrm{PO}_{4}\right)_{4}$ cell contains therefore 54 atoms that give $54 \times 3162$ vibrational modes in which are included three acoustic modes. From the factor group analysis with the standard correlation method [30] a total number of 159 optical modes are predicted with the irreducible representation:

$\Gamma_{\text {opt }} \quad 41 A_{u}+40 B_{u}+39 A_{g}+39 B_{g}$

Separating vibrational modes into internal $\left(\mathrm{PO}_{4}^{3-}\right)$ and external (lattice) modes is supported by previous works [31,32]. Internal vibrations consist of intramolecular stretching and bending mo tions of the $\mathrm{PO}_{4}^{3-}$ anions. Vibrational analysis for an undistorted $\mathrm{PO}_{4}^{3-}$ anion with $\mathrm{T}_{\mathrm{d}}$ symmetry leads to 4 modes, which are one $\mathrm{A}_{1}$ $\left[\nu_{1} ; v_{\mathrm{S}}\left(\mathrm{PO}_{4}\right)\right]$, one $\mathrm{E}\left[\nu_{2} ; \delta_{\mathrm{s}}(\mathrm{PO} 4)\right]$ and two $\mathrm{T}_{2}\left[\nu_{3,4} ; v_{\mathrm{as}}\left(\mathrm{PO}_{4}\right)\right.$ and $\left.\delta_{\text {as }}\left(\mathrm{PO}_{4}\right)\right]$ modes with frequencies appearing at 938, 420, 1017 and $567 \mathrm{~cm}^{-1}$, respectively [33]. All of them are Raman active, whereas only $\nu_{3}$ and $\nu_{4}$ are infrared active. In the $\mathrm{Na}_{2} \mathrm{Cd}_{5}\left(\mathrm{PO}_{4}\right)_{4}$ lattice, the two non equivalent tetrahedral $\mathrm{PO}_{4}^{3-}$ groups are located on general $\mathrm{C}_{1}$ positions. Their vibrational behavior can be analyzed by means of the site group method [34]. Due to the symmetry diminution from $T_{d}$ to $C_{1}$, all vibrational modes become infrared and Raman active and degeneracies are totally removed, as can be seen from Table 5.

Thus, for each tetrahedral $\mathrm{PO}_{4}^{3-}$ group, we expect, for the stretching vibrations, eight Raman active modes: $2 \nu_{1}\left(\mathrm{~A}_{\mathrm{g}}+\mathrm{B}_{\mathrm{g}}\right)+6 \nu_{3}\left(3 \mathrm{~A}_{\mathrm{g}}+3 \mathrm{~B}_{\mathrm{g}}\right)$ and eight IR active modes: $2 \nu_{1}\left(A_{u}+B_{u}\right)+6 \nu_{3}\left(3 A_{u}+3 B_{u}\right)$. As for the bending vibrations, we expect ten Raman active modes: $4 \nu_{2}\left(2 \mathrm{~A}_{\mathrm{g}}+2 \mathrm{~B}_{\mathrm{g}}\right)+6 \nu_{4}\left(3 \mathrm{~A}_{\mathrm{g}}+3 \mathrm{~B}_{\mathrm{g}}\right)$ and ten IR active modes: $4 \nu_{2}\left(2 A_{u}+2 B_{u}\right)+6 v_{4}\left(3 A_{u}+3 B_{u}\right)$. The external modes consist of the translational vibrations of $\mathrm{Na}^{+}, \mathrm{Cd}^{2+}$ and $\mathrm{PO}_{4}^{3-}$ ions and of rotational vibrations of the $\mathrm{PO}_{4}^{3-}$ groups. The corre sponding irreducible representations are obtained by subtraction as follows:

$\Gamma_{\text {ext. }} \quad \Gamma_{\text {opt. }} \quad \Gamma_{\text {int. }} \quad 23 A_{u}+22 B_{u}+21 A_{g}+21 B_{g}$

The IR and Raman spectra of the synthesized powder sample (Fig. 7) are typical of a monophosphate [35,36]. The Raman spec trum of $\mathrm{Na}_{2} \mathrm{Cd}_{5}\left(\mathrm{PO}_{4}\right)_{4}$ is dominated by a strong band situated

Table 5

Correlation between the point group $T_{d}$, the site-group $C_{1}$ and the factor group $C_{2 h}$.

\begin{tabular}{llll}
\hline Vibrational mode & $\mathrm{T}_{\mathrm{d}}$ & $\mathrm{C}_{1}$ & $\mathrm{C}_{2 \mathrm{~h}}$ \\
\hline symmetric stretching $\nu_{1} \approx 938 \mathrm{~cm}^{1}$ & $\mathrm{~A}_{1}$ & $\mathrm{~A}$ & $\mathrm{~A}_{\mathrm{g}}+\mathrm{B}_{\mathrm{g}}+\mathrm{A}_{\mathrm{u}}+\mathrm{B}_{\mathrm{u}}$ \\
symmetric bending $\nu_{2} \approx 420 \mathrm{~cm}{ }^{1}$ & $\mathrm{E}$ & $2 \mathrm{~A}$ & $2 \mathrm{~A}_{\mathrm{g}}+2 \mathrm{~B}_{\mathrm{g}}+2 \mathrm{~A}_{\mathrm{u}}+2 \mathrm{~B}_{\mathrm{u}}$ \\
antisymmetric stretching $\nu_{3} \approx 1017 \mathrm{~cm}{ }^{1}$ & $\mathrm{~T}_{2}$ & $3 \mathrm{~A}$ & $3 \mathrm{~A}_{\mathrm{g}}+3 \mathrm{~B}_{\mathrm{g}}+3 \mathrm{~A}_{\mathrm{u}}+3 \mathrm{~B}_{\mathrm{u}}$ \\
antisymmetric bending $\nu_{4} \approx 567 \mathrm{~cm}{ }^{1}$ & $\mathrm{~T}_{2}$ & $3 \mathrm{~A}$ & $3 \mathrm{~A}_{\mathrm{g}}+3 \mathrm{~B}_{\mathrm{g}}+3 \mathrm{~A}_{\mathrm{u}}+3 \mathrm{~B}_{\mathrm{u}}$ \\
\hline
\end{tabular}




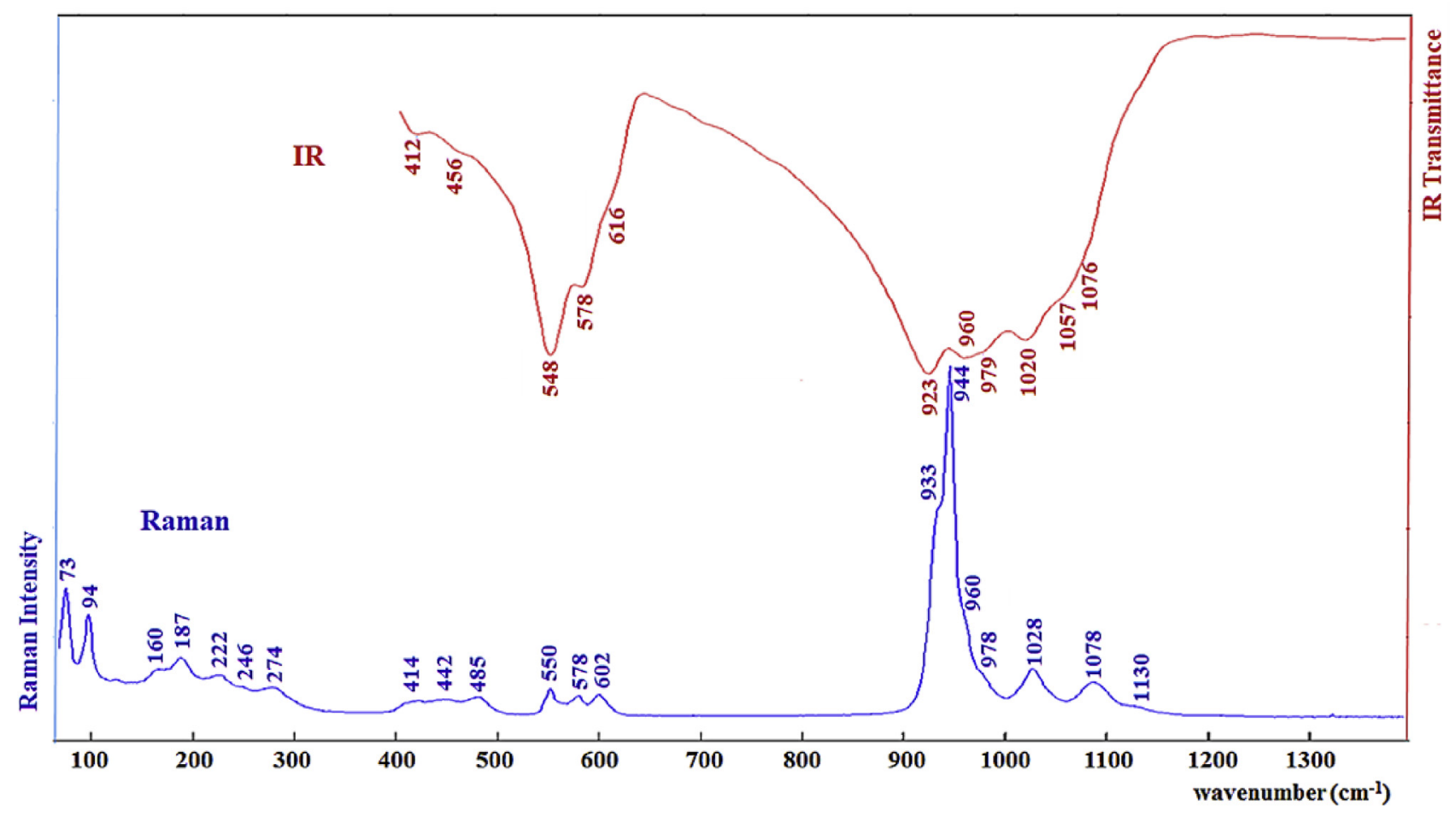

Fig. 7. Vibrational (IR and Raman) spectra of $\mathrm{Na}_{2} \mathrm{Cd}_{5}\left(\mathrm{PO}_{4}\right)_{4}$.

around $940 \mathrm{~cm}^{-1}$. The deconvolution process applied on this band leads to four intense bands centered at 931, 939, 946 and $957 \mathrm{~cm}^{-1}$ and one weak shoulder at $979 \mathrm{~cm}^{-1}$ (Fig. 8). The four intense bands appearing in the non degenerate stretching mode $\left(\nu_{1}\right)$ region can be assigned to the $2\left(\mathrm{~A}_{\mathrm{g}}+\mathrm{B}_{\mathrm{g}}\right)$ modes in agreement with the factor group analysis. The shoulder at $979 \mathrm{~cm}^{-1}$ in addition to the bands at $1000,1028,1049,1088$ and $1129 \mathrm{~cm}^{-1}$ are attributed to the asym metric stretching mode $\left(\nu_{3}\right)$. Similar observations are reported for phosphate compounds such as $\mathrm{Na}_{2} \mathrm{MMg}\left(\mathrm{PO}_{4}\right)_{2}$ with $\mathrm{M} \quad \mathrm{Ba}, \mathrm{Sr}, \mathrm{Ca}$ [37]. The weak bands, observed in the wavenumber ranges 380 $500 \mathrm{~cm}^{-1}$ and $530630 \mathrm{~cm}^{-1}$, are characteristic of the bending modes $\left(\nu_{2}\right)$ and $\left(\nu_{4}\right)$, respectively. Due to the complex overlapping of the $\nu_{2}, \nu_{3}$ and $\nu_{4}$ bands, distinction of $\mathrm{A}_{\mathrm{g}}$ and $\mathrm{B}_{\mathrm{g}}$ symmetries is not possible. Consequently, the decomposition of the Raman spectrum in the $400-1200 \mathrm{~cm}^{-1}$ spectral range allowed only 20 Raman active modes to be observed out of a total of 36 expected from the factor group analysis. In sum, the decomposition of the intense non degenerate band $\nu_{1}$ into four components, in addition to the large splitting of the weak $\nu_{2-4}$ bands, confirms the presence of two distinct $\mathrm{PO}_{4}^{3-}$ groups as determined from $\mathrm{X}$ ray studies. Bands observed below $300 \mathrm{~cm}^{-1}$ are ascribed to lattice modes. Decom position of the Raman spectrum in the $60-400 \mathrm{~cm}^{-1}$ spectral range

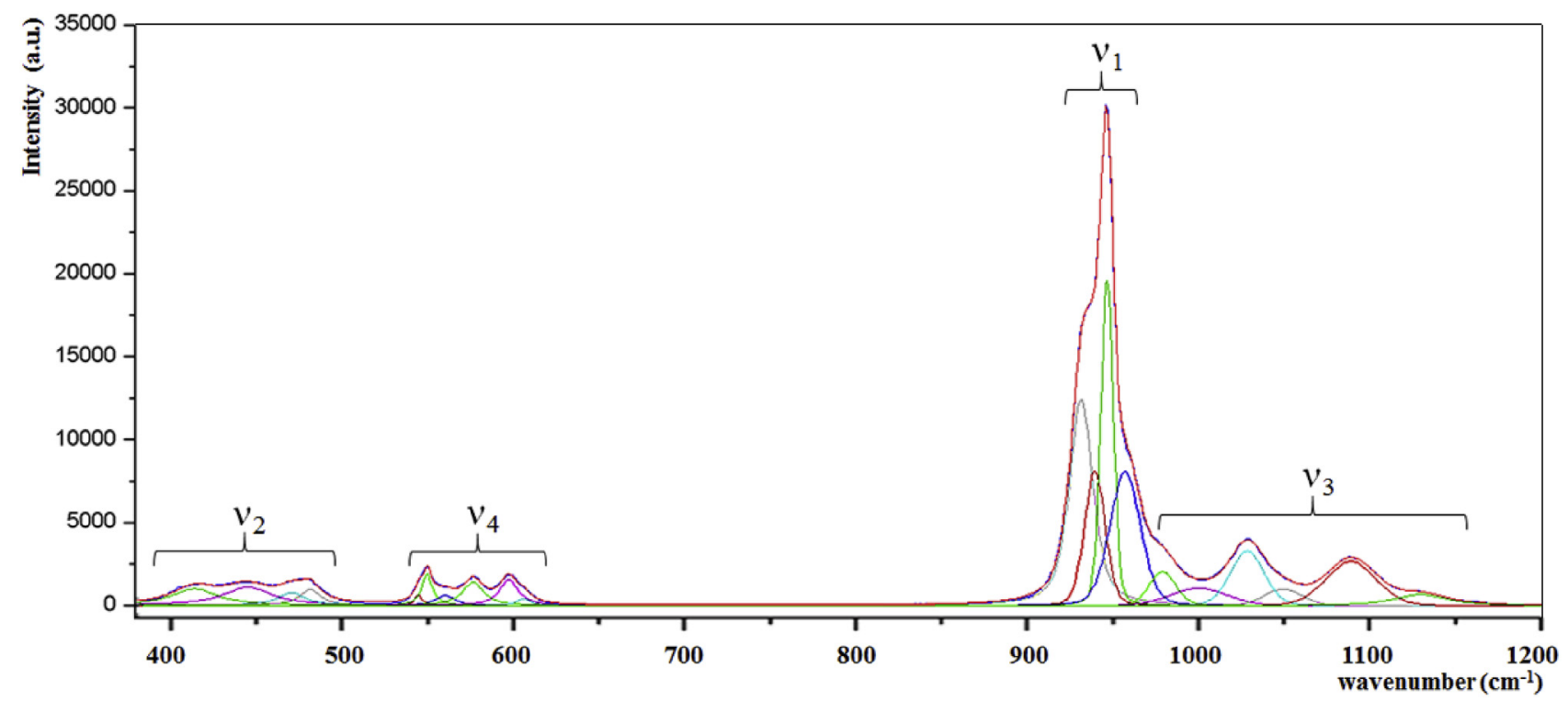

Fig. 8. Decomposition of the Raman spectrum of $\mathrm{Na}_{2} \mathrm{Cd}_{5}\left(\mathrm{PO}_{4}\right)_{4}$ in the $4001200 \mathrm{~cm}{ }^{1}$ spectral range. 
allowed only 13 Raman active modes to be observed (graph not shown). Moreover, it is difficult to assign them without polarization measurements (non available). Former studies of phosphates showed that the rotational and translational modes of the $\mathrm{PO}_{4}^{3-}$ groups were located in a broad wavenumber range, $120-300 \mathrm{~cm}^{-1}$ and active modes associated with $\mathrm{Na}^{+}$ions are observed around $50 \mathrm{~cm}^{-1}$ [38]. Thereby, among bands observed for lattice modes of $\mathrm{Na}_{2} \mathrm{Cd}_{5}\left(\mathrm{PO}_{4}\right)_{4}$, those appearing in the wavenumber range $122-275 \mathrm{~cm}^{-1}$ can be attributed to $\mathrm{PO}_{4}^{3-}$ groups rotational and translational modes while bands, which are observed between 61 and $111 \mathrm{~cm}^{-1}$, can be associated to translational modes of the $\mathrm{Na}^{+}$ and $\mathrm{Cd}^{2+}$ ions. Table 6 summarizes the main data from the deconvolution of Raman spectrum of $\mathrm{Na}_{2} \mathrm{Cd}_{5}\left(\mathrm{PO}_{4}\right)_{4}$.

Because of the broad overlapping of the bands, the infrared spectrum cannot be precisely assigned. However, some results that are consistent with the interpretation of the Raman spectrum can be reported (Table 6). The observed bands and shoulders in the wavenumber range $1076-979 \mathrm{~cm}^{-1}$ are attributed to asymmetric triply degenerate mode $\left(\nu_{3}\right)$. The bands at 960 and $923 \mathrm{~cm}^{-1}$ are assigned to symmetric $\mathrm{P}-\mathrm{O}$ stretching mode $\left(\nu_{1}\right)$. Note that the occurrence of the two distinct symmetric stretching bands with large splitting corroborates the presence of two distinct $\mathrm{PO}_{4}$ tetrahedra. The asymmetric triply degenerate mode $\left(\nu_{4}\right)$ and sym metric doubly degenerate mode $\left(\nu_{2}\right)$ of $\mathrm{O}-\mathrm{P}-\mathrm{O}$ bandings are observed in the wavenumber ranges $616-548 \mathrm{~cm}^{-1}$ and $456-412 \mathrm{~cm}^{-1}$, respectively.

\section{3. $C d^{2+}$ photoluminescence}

Photoluminescence spectra of the compound $\mathrm{Na}_{2} \mathrm{Cd}_{5}\left(\mathrm{PO}_{4}\right)_{4}$ are shown in Fig. 9. The emission is performed by setting the excitation wavelength at $210 \mathrm{~nm}$. The excitation is performed by setting the emission wavelength at $610 \mathrm{~nm}$.

The emission spectrum can be described as a broad band from $550 \mathrm{~nm}$ to $700 \mathrm{~nm}$. It is due to a $\mathrm{Cd}^{2+}$ center. While $\mathrm{Cd}^{2+}$ lumi nescence is not well known, it can be assimilated to the lumines cence of $\mathrm{Ag}^{+}$cation. The luminescence, in the visible range, is due to the $4 \mathrm{~d}^{10} 4 \mathrm{~d}^{9} 5 \mathrm{~s}$ transition [39].

The observed broad band cannot be fit by a single Gaussian

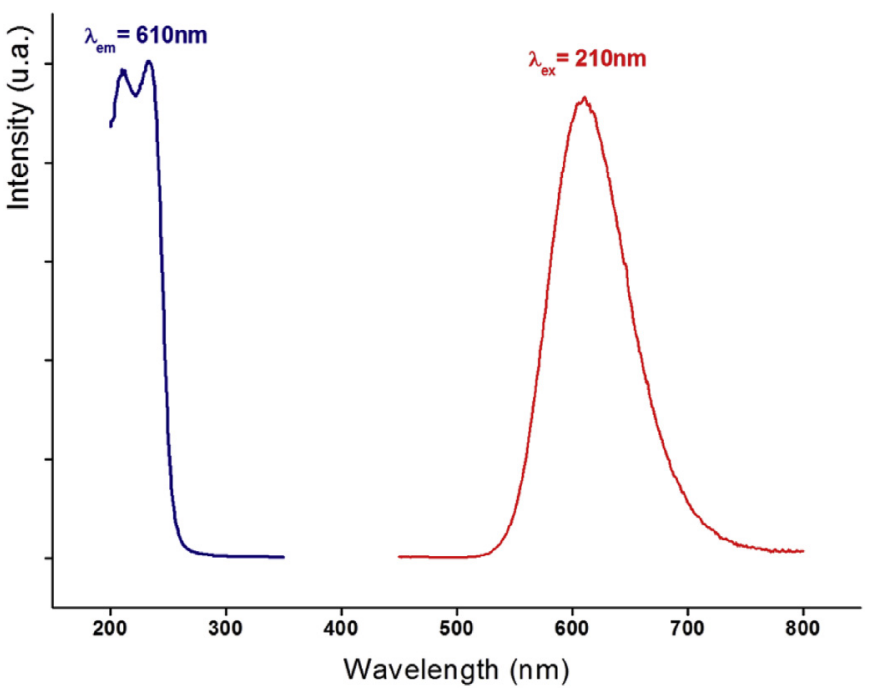

Fig. 9. Photoluminescence excitation (blue line) and emission (red line) spectra of $\mathrm{Na}_{2} \mathrm{Cd}_{5}\left(\mathrm{PO}_{4}\right)_{4}$

shape (in an energy abscise format). At least, two Gaussian bands are necessary to fit the band; see Fig. 10. The resulting bands are relevant of two ranges of crystal field surrounding cadmium cat ions. The band at the highest intensity $(0.0017 \mathrm{eV})$ is related to cadmium site having the lowest crystal field. The band at the lowest intensity $(0.00155 \mathrm{eV})$ is related to cadmium site having the highest crystal field. Regarding the crystallographic description (Figs. 2 and 3 ) and the interatomic distance (Table 3), the band at $0.0017 \mathrm{eV}$ is relevant of the six coordinated cadmium sites $\mathrm{Cd}(2)$ and $\mathrm{M}(2)$. And the band centered at $0.00155 \mathrm{eV}$ is relevant of the seven coordinated cadmium sites $\mathrm{Cd}(1)$ and $\mathrm{M}(1)$.

The difference of the broadness between these two bands could be related to the difference of average $\mathrm{Cd}-\mathrm{O}$ interatomic distances between each site. Cadmium in the $\mathrm{M}(2)$ site and in the $\mathrm{Cd}(2)$ site get an interatomic distances $\mathrm{Cd}-\mathrm{O}$ of, respectively, $2.323 \AA$ and $2.288 \AA$. Cadmium in the $\mathrm{M}(1)$ site and in the $\mathrm{Cd}(1)$ site get an

Table 6

Spectral data $\left(\mathrm{cm}^{1}\right)$ and vibrational band assignments for $\mathrm{Na}_{2} \mathrm{Cd}_{5}\left(\mathrm{PO}_{4}\right)_{4}$.

\begin{tabular}{|c|c|c|c|c|}
\hline \multicolumn{3}{|c|}{ Internal modes } & \multicolumn{2}{|l|}{ External modes } \\
\hline assignment & Raman & IR & assignment & Raman \\
\hline \multirow[t]{7}{*}{$\nu_{3} ; v_{\mathrm{as}}\left(\mathrm{PO}_{4}\right)$} & 1129 & & $\mathrm{~T}\left(\mathrm{PO}_{4}^{3}\right)+\mathrm{R}\left(\mathrm{PO}_{4}^{3}\right)$ & 275 \\
\hline & 1088 & 1076 & & 248 \\
\hline & 1049 & 1057 & & 225 \\
\hline & 1028 & 1020 & & 204 \\
\hline & 1000 & & & 187 \\
\hline & 979 & 979 & & 165 \\
\hline & & & & 136 \\
\hline \multirow[t]{5}{*}{$\nu_{1} ; v_{\mathrm{s}}\left(\mathrm{PO}_{4}\right)$} & 957 & 960 & & 122 \\
\hline & 946 & & & \\
\hline & 939 & & $\mathrm{~T}\left(\mathrm{Cd}^{2+}\right)+\mathrm{T}\left(\mathrm{Na}^{+}\right)$ & 111 \\
\hline & 931 & 923 & & 95 \\
\hline & & & & 91 \\
\hline \multirow{6}{*}{$\nu_{4} ; \delta_{\mathrm{as}}\left(\mathrm{PO}_{4}\right)$} & 608 & 616 & & 73 \\
\hline & 599 & & & 61 \\
\hline & 578 & 578 & & \\
\hline & 562 & & & \\
\hline & 552 & & & \\
\hline & 547 & 548 & & \\
\hline \multirow[t]{4}{*}{$\nu_{2} ; \delta_{\mathrm{s}}(\mathrm{PO} 4)$} & 484 & & & \\
\hline & 473 & & & \\
\hline & 447 & 456 & & \\
\hline & 416 & 412 & & \\
\hline
\end{tabular}




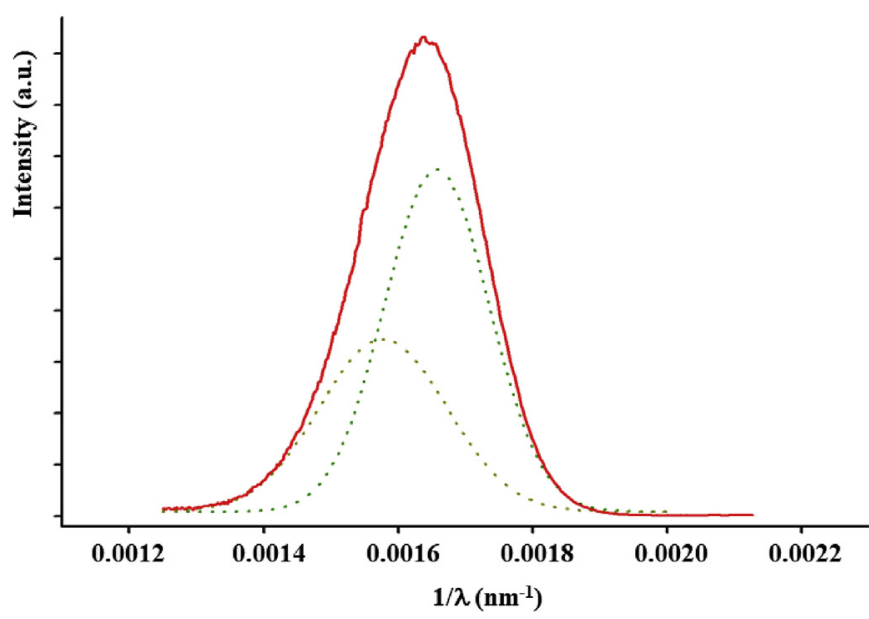

Fig. 10. Emission spectra of $\mathrm{Na}_{2} \mathrm{Cd}_{5}\left(\mathrm{PO}_{4}\right)_{4}$ under $\lambda_{\text {exc }} 220 \mathrm{~nm}$ deconvoluted in two Gaussian components.

interatomic distance of, respectively, $2.499 \AA$ and $2.402 \AA$. The dif ference of interatomic distances $\mathrm{Cd}-\mathrm{O}$ between $\mathrm{M}(2)$ and $\mathrm{Cd}(2)$ is only $1.5 \%$, while it is $4 \%$ of difference for cadmium in $\mathrm{M}(1)$ and $\mathrm{Cd}(1)$ sites. So, the band at $0.0017 \mathrm{eV}$ can be considered as composed of two Gaussian bands related to the six coordinated cadmium $\mathrm{Cd}(2)$ and $\mathrm{M}(2)$ sites. Since the crystal fields surrounding these cadmium cations are similar, the two bands are almost superposed. The band at $0.00155 \mathrm{eV}$, relevant of the seven coordinated cadmium $\mathrm{Cd}(1)$ and $\mathrm{M}(1)$ sites, can also be considered as composed of two Gaussian bands. Since the crystal fields surrounding these cadmium cations are quite different, the bands are more separated, inducing a broadening of the overall band.

Furthermore, the absence of additional bands confirms the pu rity of the powder sample. Indeed, in case of Cd cluster, of cadmium in interstitial position, additional photoluminescent phenomena would appear [40]. Photoluminescence is quite more sensible than $\mathrm{X}$ ray diffraction. So, the single phase state of the powder sample is clearly identified.

\section{Conclusion}

The sodium cadmium phosphate $\mathrm{Na}_{2} \mathrm{Cd}_{5}\left(\mathrm{PO}_{4}\right)_{4}$ was synthesized and its crystal structure investigated. It is a new member within the $\mathrm{Na}_{2} \mathrm{M}_{5}\left(\mathrm{PO}_{4}\right)_{4}$ series of compounds. Its unique structure type is built from $\left(\mathrm{Na}_{3 / 4}, \mathrm{Cd}_{1 / 4}\right) \mathrm{O}_{7},\left(\mathrm{Cd}_{3 / 4}, \mathrm{Na}_{1 / 4}\right) \mathrm{O}_{6}$ and $\mathrm{CdO}_{\mathrm{x}}(\mathrm{x} \quad 6,7)$ polyhedra and $\mathrm{PO}_{4}$ tetrahedra linked through common corners or edges. The resulting complex three dimensional framework consists of [ $\left(\mathrm{Na}_{3}\right.$ $\left.\left.{ }_{4}, \mathrm{Cd}_{1 / 4}\right)_{2}\left(\mathrm{Cd}_{3 / 4}, \mathrm{Na}_{1 / 4}\right)_{2} \mathrm{Cd}_{3} \mathrm{O}_{16}\right]_{\infty}$ layers stacked parallel to the (2 $0-3$ ) plane and interconnected both directly and via $\mathrm{PO}_{4}$ tetrahedra by sharing common corners and edges. The vibrational spectro scopic results are in agreement with the factor group analysis and with the presence of two different $\mathrm{PO}_{4}^{3-}$ groups determined from the $\mathrm{X}$ ray diffraction study. Photoluminescence analysis evidences of two kinds of oxygen environments for the cadmium atoms, in line with the crystallographic description. The covalent character of this structure with its multiple sites occupied by cadmium cations should potentially make it a host material for optically active ions. As a consequence, attractive photoluminescence properties may be expected.

\section{Appendix A. Supplementary data}

Supplementary data to this article can be found online at https://doi.org/10.1016/j.molstruc.2019.126963.

\section{References}

[1] M. Kottaisamy, R. Jagannathant, P. Jeyagopal, R.P. Rao, R.L. Narayanan, Eu ${ }^{2+}$ luminescence in $\mathrm{M}_{5}\left(\mathrm{PO}_{4}\right)_{3} \mathrm{X}$ apatites, where $\mathrm{M}$ is $\mathrm{Ca}^{2+}, \mathrm{Sr}^{2+}$ and $\mathrm{Ba}^{2+}$ and $\mathrm{X}$ is F, CI , Br and OH , J. Phys. D Appl. Phys. 27 (1994) 22107215.

[2] X. Zhang, J. Zhang, J. Huang, X. Tang, M. Gong, Synthesis and luminescence of $\mathrm{Eu}^{2+}$-doped alkaline-earth apatites for application in white LED, J. Lumin. 130 (2010) 554559

[3] J. Zhoua, Q. Liua, Z. Xia, Structural construction and photoluminescence tuning via energy transfer in apatite-type solid-state phosphors, J. Mater. Chem. C 6 (2018) 43714383.

[4] J. Lü, Y. Huang, L. Shi, H.J. Seo, The luminescence properties of Eu ${ }^{2+}$ doped $\mathrm{Na}_{2} \mathrm{CaMg}\left(\mathrm{PO}_{4}\right)_{2}$ phosphor, Appl. Phys. A 99 (2010) 859863.

[5] D. Geng, M. Shang, Y. Zhang, H. Lian, J. Lin, Temperature dependent luminescence and energy transfer properties of $\mathrm{Na}_{2} \mathrm{SrMg}\left(\mathrm{PO}_{4}\right)_{2}: \mathrm{Eu}^{2+}, \mathrm{Mn}^{2+}$ phosphors, Dalton Trans. 42 (2013) 1537215380.

[6] A. Boukhris, B. Glorieux, M. Ben Amara, X-ray diffraction, ${ }^{31} \mathrm{P}$ NMR and europium photoluminescence properties of the $\mathrm{Na}_{2} \mathrm{Ba}_{1}{ }_{x} \mathrm{Sr}_{x} \mathrm{Mg}\left(\mathrm{PO}_{4}\right)_{2}$ system related to the glaserite type structure, J. Mol. Struct. 1083 (2015) 319329.

[7] M. Aboussatar, A. Mbarek, H. Naili, M. El-Ghozzi, G. Chadeyron, D. Avignant, D. Zambon, Phase equilibria in the NaF-CdO-NaPO 3 system at $873 \mathrm{~K}$ and crystal structure and physico-chemical characterizations of the new $\mathrm{Na}_{2} \mathrm{Cd}$ $\mathrm{PO}_{4} \mathrm{~F}$ fluorophosphate, J. Solid State Chem. 248 (2017) 7586.

[8] G. Celotti, E. Landi, A misunderstood member of the nagelschmidtite family unveiled: structure of $\mathrm{Ca}_{5} \mathrm{Na}_{2}\left(\mathrm{PO}_{4}\right)_{4}$ from X-ray powder diffraction data, J. Eur. Ceram. Soc. 23 (2003) 851858.

[9] R. Widmer, F. Gfeller, T. Armbruster, Structural and crystal chemical investigation of intermediate phases in the system $\mathrm{Ca}_{2} \mathrm{SiO}_{4} \mathrm{Ca}_{3}\left(\mathrm{PO}_{4}\right)_{2} \mathrm{CaNaPO}_{4}$, J. Am. Ceram. Soc. 9812 (2015) 39563965.

[10] J. Yamakawa, T. Yamada, A. Kawahara, Un monophosphate de magnésium et sodium, Acta Crystallogr. C50 (1994) 986988.

[11] A.G. Nord, P. Kierkegaard, The crystal structure of $\mathrm{Mg}_{3}\left(\mathrm{PO}_{4}\right)_{2}$, Acta Chem. Scand. 22 (1968) 14661474.

[12] L.N. Ji, H.W. Ma, J.B. Li, J.K. Liang, B.J. Sun, Y.H. Liu, J.Y. Zhang, G.H. Rao, A new structure type of phosphate: crystal structure of $\mathrm{Na}_{2} \mathrm{Zn}_{5}\left(\mathrm{PO}_{4}\right)_{4}$, J. Solid State Chem. 180 (2007) 22562261.

[13] H.Y. Ng, W.T.A. Harrison, Monoclinic $\mathrm{NaZnPO}_{4}-\mathrm{ABW}$, a new modification of the zeolite ABW structure type containing elliptical eight-ring channels, Microporous Mesoporous Mater. 23 (1998) 197202.

[14] Pechini M P. Method of Preparing Lead and Alkaline Earth Titanates and Niobates and Coating Method Using the Same to Form a Capacitor. US Patent. (1967) No.3.330.697.

[15] N. Walker, D. Stuart, An Empirical method for correcting diffractometer data absorption effets, Acta Crystallogr. A39 (1983) 158166.

[16] A. Altomare, G. Cascarano, C. Giacovazzo, A. Guagliardi, Completion and refinement of crystal structures with SIR92, J. Appl. Crystallogr. 26 (1993) 343350.

[17] G.M. Sheldrick, SHELXL-97, Program for Crystal Structure Refinement, University of Gottingen, Germany, 1997.

[18] R.D. Shannon, Revised effective ionic radii and systematic studies of interatomic distances in halides and chalcogenides, Acta Crystallogr. A32 (1976) 751767.

[19] L.J. Farrugia, WinGX suite for small-molecule single-crystal crystallography, J. Appl. Crystallogr. 32 (1999) 837838.

[20] R. Hoppe, S. Voigt, H. Glaum, J. Kissel, H.P. Müller, K. Bernet, A new route to charge distributions in ionic solids, J. Less Common. Met. 156 (1989) 105122.

[21] M. Nespolo, G. Ferraris, G. Ivaldi, R. Hoppe, Charge distribution as a tool to investigate structural details. II. Extension to hydrogen bonds, distorted, and hetero-ligand polyhedra, Acta Crystallogr. B57 (2001) 652664

[22] A. Juhin, G. Morin, E. Elkaïm, D.J. Frost, M. Fialin, F. Juillot, G. Calas, Structure refinement of a synthetic knorringite, $\mathrm{Mg}_{3}\left(\mathrm{Cr}_{0.8} \mathrm{Mg}_{0.1} \mathrm{Si}_{0.1}\right)_{2}\left(\mathrm{SiO}_{4}\right)_{3}$, Am. Mineral. 95 (2010) 5963.

[23] G. Donnay, R. Allmann, How to recognize $\mathrm{O}^{2}, \mathrm{OH}$, and $\mathrm{H}_{2} \mathrm{O}$ in crystal structures determined by x-rays, Am. Mineral. 55 (1970) 10031015.

[24] M. Ben Amara, R. Olazcuaga, G. Le Flem, M. Vlasse, The crystal structure of cadmium orthophosphate $\mathrm{Cd}_{4} \mathrm{Na}\left(\mathrm{PO}_{4}\right)_{3}$, Acta Crystallogr. B35 (1979) 15671569.

[25] E. Holt, S. Drai, R. Olazcuaga, M. Vlasse, The crystal structure of cadmium orthovanadate $\mathrm{KCd}_{4}\left(\mathrm{VO}_{4}\right)_{3}$, Acta Crystallogr. B33 (1977) 9598.

[26] Yu A. Ivanov, M.A. Simonov, N.V. Belov, Crystal structure of the Na,Cd orthophosphate $\mathrm{NaCdPO}_{4}$, Kristallografiya 19 (1974) 163164.

[27] W.H. Baur, The geometry of polyhedral distortions. Predictive relationships for the phosphate group, Acta Crystallogr. B30 (1974) 11951215.

[28] L. Elammari, B. Elouadi, Structure of $\mathrm{LiCdPO}_{4}$, Acta Crystallogr. C44 (1988) $13571359(\mathrm{E})$.

[29] M.P. Orlova, D.B. Kitaev, M.L. Spiridonova, N.V. Zubkova, Yu K. Kabalov, A.I. Orlova, Structure refinement of cadmium cerium(IV) phosphate $\mathrm{Cd}_{0.5} \mathrm{Ce}_{2}\left(\mathrm{PO}_{4}\right)_{3}$, crystallogr, For. Rep. 50 (2005) 918922.

[30] W.G. Fateley, F.R. Dollish, N.T. Mc Davitt, F.F. Bentley, Infrared and Raman Selection Rules for Molecular and Lattice Vibrations the Correlation Method, Wiley, New York, 1972.

[31] G. Venkataraman, V.C. Sahni, External vibrations in complex crystals, Rev. Mod. Phys. 424 (1970) 409470.

[32] P. Tarte, A. Rulmont, C. Merckaert-ansay, Vibrational spectrum of nasicon-like, 
rhombohedral orthophosphates $\mathrm{M}^{\mathrm{I}} \mathrm{M}_{2}^{\mathrm{IV}}\left(\mathrm{PO}_{4}\right)_{3}$, Spectrochim. Acta 42A-9 (1986) 10091016.

[33] K. Nakamoto, Infrared and Raman Spectra of Inorganic and Coordination Compounds, fourth ed., Wiley \& Sons, New York, 1986, p. 78.

[34] R.S. Halford, Motions of molecules in condensed systems: I. Selection rules, relative intensities, and orientation effects for Raman and infra-red spectra, J. Chem. Phys. 141 (1946) 815.

[35] V.S. Kurazhkovskaya, D.M. Bykov, E.Yu Borovikova, N.Yu Boldyrev, L. Mikhalitsyn, A.I. Orlova, Vibrational spectra and factor group analysis of lanthanide and zirconium phosphates $\mathrm{M}^{\mathrm{III}}{ }_{0.33} \mathrm{Zr}_{2}\left(\mathrm{PO}_{4}\right)_{3}$, where $\mathrm{M}^{\mathrm{III}} \mathrm{Y}$, La Lu, Vib. Spectrosc. 52 (2010) 137143.

[36] A. Jillvenkatesa, R.A. Condrate Sr., The Infrared and Raman spectra of $\beta$ - and $\alpha-$ tricalcium phosphate $\left(\mathrm{Ca}_{3}\left(\mathrm{PO}_{4}\right)_{2}\right)$, Spectrosc. Lett. 318 (1998) 16191634.

[37] Y. Yonesaki, C. Matsuda, Crystal structure of $\mathrm{Na}_{2} \mathrm{MMgP}_{2} \mathrm{O}_{8}$ (M: Ba, $\mathrm{Sr}, \mathrm{Ca}$ ) orthophosphates and their luminescence properties by $\mathrm{Eu}^{2+}$; analogous structural behaviors of glaserite-type phosphates and silicates, J. Solid State Chem. 184 (2011) 32473252.

[38] M. Barj, G. Lucazeau, C. Delmas, Raman and infrared spectra of some chromium nasicon-type materials: short-range disorder characterization, J. Solid State Chem. 100 (1992) 141150.

[39] K. Narita, Luminescence of Ag-exchanged zeolite 13X, J. Lumin. 4 (1971) 7380.

[40] E. Radzhabov, M. Kirm, Triplet luminescence of cadmium centres in alkalineearth fluoride crystals, J. Phys. Condens. Matter 17 (2005) 58215830. 